\title{
Antioxidant, antimicrobial activity and therapeutic profile of Satureja hortensis from Erzincan province
}

\section{Erzincan bölgesinde toplanan Satureja hortensis bitkisinin antioksidan, antimikrobiyal aktivite ve terapotik profilinin belirlenmesi}

Falah Saleh Mohammed ${ }^{1}$, Taner Dastan², Mustafa Sevindik ${ }^{3}$, Zeliha Selamoglu ${ }^{4}$

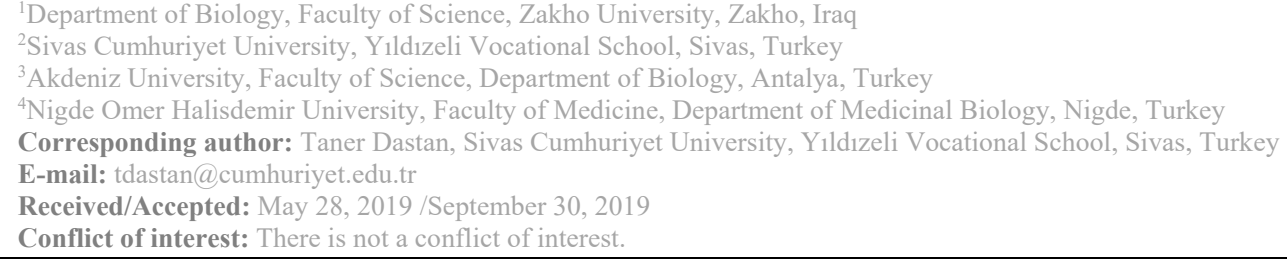

\begin{abstract}
SUMMARY
In this study, ethanol $(\mathrm{EtOH})$, methanol $(\mathrm{MeOH})$ and dichloromethane (DCM) extracts of the plant samples were obtained. The total antioxidant status (TAS), total oxidant status (TOS), oxidative stress index (OSI) and antimicrobial activity of the different extracts of Satureja hortensis L. collected from Erzincan (Turkey) province were determined. Rel Assay Diagnostics kits are used to determine TAS, TOS and OSI values. Antimicrobial activity was determined with 9 different bacteria and fungi strain (Staphylococcus aureus, Staphylococcus aureus MRSA, Enterococcus faecalis, Escherichia coli, Pseudomonas aeruginosa, Acinetobacter baumannii, Candida albicans, Candida krusei and Candida glabrata) using modified agar dilution method. The plant extracts in this study were antimicrobially effective between $25-800 \mu \mathrm{g} / \mathrm{mL}$ concentrations level on 9 different microorganisms strain. Also the plant extracts showed the highest activity against $A$. baumannii. As a result, S. hortensis plant from Erzincan province could be a good natural antioxidant and antimicrobial source with its high antioxidant and low oxidant capacity
\end{abstract}

Keywords: Antimicrobial, antioxidant, medicinal plants, oxidant, Satureja hortensis
(D) Falah Saleh Mohammed
(D) Taner Dastan
(D) Mustafa Sevindik
(D) Zeliha Selamoglu

ORCID IDs of the authors: F.S.M. 0000-0001-9083-1876 T.D. 0000-0003-0296-6979 M.S. 0000-0001-7223-2220 Z.S. $0000-0001-9056-6435$

\section{ÖZET}

Bu çalışmada Erzincan (Türkiye) ilinden toplanan Satureja hortensis L. bitkisinin etanol, metanol ve diklorometan özütleri elde edilmiştir. Daha sonra bitkinin tüm özütlerinin toplam antioksidan seviyesi (TAS), toplam oksidan seviyesi (TOS), oksidatif stres indeksi (OSI) ve antimikrobiyal aktivitesi belirlenmiştir. Bitkinin TAS, TOS ve OSI değerlerini tespit etmek için Rel Assay Diagnostics kitler kullanılmıştır. Bitkinin antimikrobiyal aktivitesi 9 farklı bakteri ve mantar suşu (Staphylococcus aureus, Staphylococcus aureus MRSA, Enterococcus faecalis, Escherichia coli, Pseudomonas aeruginosa, Acinetobacter baumannii, Candida albicans, Candida krusei and Candida glabrata) üzerinde, modifiye edilmiş agar dilüsyon metodu kullanılarak belirlenmiştir. Bu çalışmadaki bitki özütleri 9 farklı bakteri ve mantar suşu üzerinde 25-800 $\mu \mathrm{g} / \mathrm{mL}$ arasında değişen konsantrasyon seviyelerinde antimikrobiyal olarak etkili bulunmuştur. Ayrıca bitki ekstraktları en yüksek aktiviteyi A. baumannii'ye karşı sergilemiştir. Sonuç olarak, Erzincan ilinden toplanan S. 
hortensis bitkisinin yüksek antioksidan ve düşük oksidan kapasitesi ile iyi bir doğal antioksidan ve antimikrobiyal kaynak olabileceği düșünülmektedir.

Anahtar sözcükler: Antimikrobiyal, antioksidan, oksidan, Satureja hortensis, tıbbi bitki

\section{INTRODUCTION}

People have become dependent on nature because of they need drug, shelter, food, perfume, clothes, spices, fertilizer and transportation vehicles. This is the case in countries where long-term use of herbal medicines is constantly being developed. The medical and financial development and recognition of these plants is increasing in both developed and developing countries ${ }^{1,2}$. Today, millions of people around the world consume plant-based medicines as part of the traditional medicine for a range of medical disorders. The use of alternative medicine in developing countries directly contributes to the socio-economic situation and the welfare of rural communities $^{3}$. Herbal drugs, especially in recent years in Europe and North America, has an annual market share of \% 10-20 percent. In addition, there are many herbal products sold for health food, food supplements, herbal teas, various other health and personal care related purposes ${ }^{4}$.

S. hortensis naturally appearing in Turkey, it is an annual plant of the Lamiaceae members. This plant is also cultivated in Spain, Germany, and England 5 . $S$. hortensis is used in the treatment of some microbial illness and cancer. The phenolic compounds in volatile oil of this plant are especially very effective to treat this kind of illness. It also has stimulant, degassing, antipyretic and aphrodisiac properties ${ }^{6,7}$. In this context, to determine the TAS, TOS, OSI capacities and antimicrobial activities of different extracts of $S$. hortensis plant from Erzincan province were aimed.

\section{MATERIAL AND METHODS}

The identification of S. hortensis (B8 Erzincan, Tercan, $1450 \mathrm{~m}, 18.07 .2018$. M. Sevindik 1559) was made by benefiting from the 7th volume of Flora of Turkey ${ }^{8}$. The samples transported to the laboratory environment under suitable conditions were extracted with ethanol $(\mathrm{EtOH})$, methanol $(\mathrm{MeOH})$ and dichloromethane (DCM) in the extractor (Gerhardt EV 14). The extracts were concentrated by rotary evaporator (Heidolph Laborota 4000 Rotary Evaporator).

\section{Determination of TAS, TOS and OSI Values}

TAS, TOS and OSI values of $S$. hortensis were determined by using commercial Rel Assay diagnostics kits. Trolox was used as calibrator in the TAS tests and hydrogen peroxide was used in the TOS tests ${ }^{9,10}$. OSI (Arbitrary Unit $=\mathrm{AU}$ ) value was determined according to the following formula ${ }^{10}$.

$$
\text { OSI }(\mathrm{AU})=\frac{\mathrm{TOS}, \mu \mathrm{mol} \mathrm{H}_{2} \mathrm{O}_{2} \text { equiv./L }}{\mathrm{TAS}, \mathrm{mmol} \text { Trolox equiv./L X } 10}
$$

\section{Antibacterial and Antifungal Activity Tests}

The antibacterial and antifungal activity capacities of $\mathrm{EtOH}, \mathrm{MeOH}$ and DCM extracts of the plant samples were determined using the agar dilution method recommended by the Clinical and Laboratory Standards Institute (CLSI) and the European Committee on Antimicrobial Susceptibility Testing (EUCAST). For each extract used, minimal inhibitor concentrations (MIC) were tested against standard bacteria and fungus strains. Staphylococcus aureus ATCC 29213, S. aureus MRSA ATCC 43300, Enterococcus faecalis ATCC 29212, Escherichia coli ATCC 25922, Pseudomonas aeruginosa ATCC 27853 and Acinetobacter baumannii ATCC 19606 were used as bacteria strains. Candida albicans ATCC 10231, C. krusei ATCC 34135 ATCC 13803 ve C. glabrata ATCC 90030 were used as fungus strains. Pre-culturing of bacterial strains was carried out on Muller Hinton Broth medium. Fungus strains were made on RPMI 1640 Broth medium. To obtain a standard inoculum, the blur of bacteria and fungi was prepared according to McFarland 0.5. All extracts were tested at $12.5-800 \mu \mathrm{g} / \mathrm{mL}$ concentrations and all dilutions were made with distilled water. Fluconazole and amphotericin B for fungi, Amikacin, Ampicillin and Ciprofloxacin for bacteria were used as reference drugs. The lowest concentration which prevents the growth of bacteria and fungi was determined as $\mathrm{MIC}^{11-16}$.

\section{RESULTS and DISCUSSION}

\section{Antioxidant Activity Results}

TAS, TOS and OSI values of the different extracts of $S$. hortensis plant from Erzincan province were determined by using the commercial kits with the $99,9 \%$ reliability for the first time. The values obtained are shown in Table 1. 
Table 1: TAS, TOS and OSI values of S. hortensis

\begin{tabular}{llll}
\hline & $\begin{array}{l}\text { TAS } \\
\mathrm{mmol} / \mathrm{L}\end{array}$ & $\begin{array}{l}\text { TOS } \\
\mu \mathrm{mol} / \mathrm{L}\end{array}$ & OSI \\
\hline S. hortensis & $5.403 \pm 0.102$ & $3.537 \pm 0.076$ & $0.065 \pm 0.003$ \\
\hline
\end{tabular}

Values are presented as mean $\pm \mathrm{SD}$; number samples $\mathrm{n}=6$, Experiments were made in 5 parallels

In previous studies on different plant species, TAS value of Mentha longifolia subsp. longifolia was reported $3.628 \mathrm{mmol} / \mathrm{L}$, TOS value was 4.046 $\mu \mathrm{mol} / \mathrm{L}$ and OSI value was $0.112^{2}$. In a different study, TAS value of Salvia multicaulis was reported $6.434 \mathrm{mmol} / \mathrm{L}$, TOS value was 22.441 $\mu \mathrm{mol} / \mathrm{L}$ and OSI value was $0.349^{17}$. In addition, TAS values of Thermopsis turcica, Brassica rapa and Calendula officinalis have been reported as $2.06 \mathrm{mmol} / \mathrm{L}, 1.25 \mathrm{mmol} / \mathrm{L}$ and $5.55 \mathrm{mmol} / \mathrm{L}$, respectively ${ }^{18-20}$. In our study, TAS value of $S$. hortensis was found to be $5.403 \pm 0.102 \mathrm{mmol} / \mathrm{L}$, TOS value was $3.537 \pm 0.076 \mu \mathrm{mol} / \mathrm{L}$ and OSI value was $0.065 \pm 0.003$. Compared to these studies, TAS values of $S$. hortensis was found higher than $M$. longifolia subsp. longifolia, T. turcica and B. rapa. TAS values of $S$. hortensis was found lower than $S$. multicaulis and C. officinalis plants. This difference in TAS values is due to the capacity to produce endogenous antioxidants of plants. Plant extracts, foodstuffs and some herbal drinks are considered to be important sources of dietary antioxidants, which have positive effects on human health and aging process ${ }^{21}$. In previous studies, different extracts of $S$. hortensis collected another places were used by different researchers and antioxidant potential was reported with generally
ABTS cation reducing methods etc. ${ }^{22-26 .}$ In our study, it was determined that $S$. hortensis was high antioxidant potential and this data was showed with the more reliable determining methods with the rel assay diagnostics kits.

Furthermore, TOS and OSI values of S. hortensis was found lower than $M$. longifolia subsp. longifolia and S. multicaulis. In this context, it is seen that $S$. hortensis produces and accumulates less reactive oxygen species as a result of environmental and metabolic activities. When OSI values are considered, it is seen that $S$. hortensis appears to suppress the oxidant compounds by producing endogenous antioxidants. As a result, it was determined that $S$. hortensis can be used as a good natural antioxidant source due to its low TOS and OSI value as well as high TAS value. So, it can be used as a well antioxidant source of diet.

\section{Antimicrobial Activity Results}

$\mathrm{EtOH}, \mathrm{MeOH}$ and DCM extracts of S. hortensis were used and the lowest extract concentrations were determined to prevent proliferation against $S$. aureus, S. aureus MRSA, E. faecalis, E. coli, P. aeruginosa, A. baumannii, C. albicans, C. krusei and C. glabrata. The results are shown in Table 2.

Table 2: Antibacterial and Antifungal Activity of different extracts from S. hortensis.

\begin{tabular}{|c|c|c|c|c|c|c|c|c|c|}
\hline & S. aureus & $\begin{array}{l}\text { S. aureus } \\
\text { MRSA }\end{array}$ & E. faecalis & E. coli & $\begin{array}{l}P . \\
\text { aeruginosa }\end{array}$ & $\begin{array}{l}\text { A. } \\
\text { baumannii }\end{array}$ & $\begin{array}{l}\text { C. } \\
\text { albicans }\end{array}$ & $\begin{array}{l}\text { C. } \\
\text { glabrata }\end{array}$ & $\begin{array}{l}\text { C. } \\
\text { krusei }\end{array}$ \\
\hline $\mathrm{EtOH}$ & 25 & 25 & 200 & 100 & 200 & 25 & 100 & 100 & 100 \\
\hline $\mathrm{MeOH}$ & 50 & 50 & 200 & 100 & 200 & 25 & 400 & 400 & 400 \\
\hline DCM & 50 & 50 & 200 & 200 & 200 & 25 & 400 & 400 & 800 \\
\hline Ampicillin & 1.56 & 3.12 & 1.56 & 3.12 & 3.12 & - & - & - & - \\
\hline Amikacin & - & - & - & 1.56 & 3.12 & 3.12 & - & - & - \\
\hline Ciprofloksasin & 1.56 & 3.12 & 1.56 & 1.56 & 3.12 & 3.12 & - & - & - \\
\hline Flukanazol & - & - & - & - & - & - & 3.12 & 3.12 & - \\
\hline Amfoterisin B & - & - & - & - & - & - & 3.12 & 3.12 & 3.12 \\
\hline
\end{tabular}

*The MIC values are presented in units of $\mu \mathrm{g} / \mathrm{mL}$. 
EtOH, MeOH and DCM extracts of S. hortensis showed the highest activity against $A$. baumannii. The EtOH extract of the plant showed higher activity than the other extracts. In previous studies, essential oil of $S$. hortensis has been reported to be effective on Erwinia amylovora ${ }^{27}$. In a different study, $\mathrm{MeOH}$ and hexane extracts of $S$. hortensis have been reported to be effective against Bacillus amyloliquefaciens, B. atrophaeus, B. licheniformis, $B$. macerans, B. megaterium, B. pumilus, $B$. sphaericus, B. substilis, Escherichia coli, Kocuria varians, Micrococcus luteus, Pantoea agglomerans and Candida albicans at different concentrations $^{28}$. In another study, it was reported that essential oil of $S$. hortensis was effective against Staphylococcus aureus, Bacillus cereus, Escherichia coli, Pseudomonas aeruginosa and Salmonella typhimurium at different concentrations $^{28}$. In this study, the plant extracts were antimicrobially effective between 25-800 $\mu \mathrm{g} / \mathrm{mL}$ concentrations level on 9 different microorganisms strain. The antimicrobial activity values were significant when they were $100 \mu \mathrm{g} / \mathrm{mL}$ concentrations or lower. Also they were reported to be moderately effective in the range of 100 $\mu \mathrm{g} / \mathrm{mL}<$ MIC $\leq 625 \mu \mathrm{g} / \mathrm{mL}$ and weakly effective when the MIC value was more than $625 \mu \mathrm{g} / \mathrm{mL}^{29,30}$. According to the results, EtOH extract was generally found to be strong antimicrobial activities on all microorganisms except for $E$. faecalis and $P$. aeruginosa. $\mathrm{MeOH}$ and $\mathrm{DCM}$ extracts had strong antimicrobial activities on $2 S$. aureus strain and $A$. baumannii microorganisms. In addition, $\mathrm{MeOH}$ and DCM extracts were almost moderatelly effective on the other bacteria and fungi strains. Finally, S. hortensis can be a natural antimicrobial agent against microorganisms that we tested.

\section{CONCLUSION}

In this study, antioxidant and antimicrobial activities of $S$. hortensis were determined. In this regards, plant extracts have been found high antioxidant and low oxidant activity. Also, plant extracts showed the highest antimicrobial activities against almost all microorganisms. But the best antimicrobial activity was obtained on $A$. baumannii. In conclusion, $S$. hortensis can be a natural antioxidant and antimicrobial agent that can be taken by diet.

\section{REFERENCES}

1. Dar RA, Shahnawaz M, Qazi PH. General overview of medicinal plants: A review. The Journal of Phytopharmacology. 2017;6(6): 349-351.
2. Sevindik M, Akgul H, Pehlivan M, Selamoglu Z. Determination of therapeutic potential of Mentha longifolia ssp. longifolia. Fresen Environ Bull. 2017;26: 4757-4763.

3. Namukobe J, Kasenene JM, Kiremire BT, Byamukama R, Kamatenesi-Mugisha M, Krief S, et al. Traditional plants used for medicinal purposes by local communities around the Northern sector of Kibale National Park, Uganda. Journal of Ethnopharmacology. 2011;136(1): 236-245.

4. Hamilton AC. Medicinal plants, conservation and livelihoods. Biodiversity \& Conservation. 2004;13(8): 1477-1517.

5. Peter KV (Ed.). Handbook of herbs and spices. Elsevier. 2012.

6. Deans SG, Svoboda KP. Antibacterial activity of summer savory (S. hortensis L.) essential oil and its constituents. Journal of Horticultural Science. 1989;64(2):205-210.

7. Karami-Osboo R, Khodaverdi M, Ali-Akbari F. Antibacterial Effect of Effective Compounds of Satureja hortensis and Thymus vulgaris Essential Oils against Erwinia amylovora. J. Agr. Sci. Tech. 2010;12: 35-45

8. Davis PH, Mill RR, Tan K. Flora of Turkey and the east Aegean 1slands. Edinburg Univsersty Press. 1982;7:322-323.

9. Erel O. A novel automated direct measurement method for total antioxidant capacity using a new generation, more stable ABTS radical cation. Clinical biochemistry. 2004;37(4):277-285.

10. Erel O. A new automated colorimetric method for measuring total oxidant status. Clinical biochemistry. 2005;38(12):1103-1111.

11. Bauer AW, Kirby WM, Sherris JC, Turck M. Antibiotic susceptibility testing by a standardized single disk method. Am J Clin Pathol. 1966;45:493-496.

12. Hindler J, Hochstein L, Howell A. Preparation of routine media and reagents used in antimicrobial susceptibility testing. Part 1 . McFarland standards, p. 5.19.1-5.19.6. In H. D. Isenberg (ed) Clinical microbiology procedures handbook, vol. 1. American Society for Microbiology, Washington, D.C. 1992.

13. CLSI (The Clinical and Laboratory Standards Institute). Antimicrobial Susceptibility Testing of Anaerobic Bacteria; Approved Standard-Eighth Edition (M11-A8) (2012). 
14. EUCAST (European Committee on Antimicrobial Susceptibility Testing). Breakpoint tables Fungal isolate for interpretation of MICs. (2014) Version 7.0.

15. Matuschek E, Brown DF, Kahlmeter G. Development of the EUCAST disk diffusion antimicrobial susceptibility testing method and its implementation in routine microbiology laboratories, Clin Microbiol Infect. 2017;20:255-266.

16. EUCAST (European Committee on Antimicrobial Susceptibility Testing). Breakpoint tables for Bacteria interpretation of MICs and zone diameters (2015) Version 5.0

17. Pehlivan M, Sevindik M. Antioxidant and antimicrobial activities of Salvia multicaulis. Turkish Journal of AgricultureFood Science and Technology. 2018;6(5): 628-631.

18. Aksoy L, Kolay E, Ağılönü Y, Aslan Z, Kargıŏlu M. Free radical scavenging activity, total phenolic content, total antioxidant status, and total oxidant status of endemic T. turcica. Saudi journal of biological sciences. 2013;20(3):235-239.

19. Gul S, Ahmed S, Gul H, Shad KF, Zia-Ul-Haq M, Badiu D. The antioxidant potential of Brassica rapa L. on glutathione peroxidase, superoxide dismutase enzymes and total antioxidant status. Romanian Review of Laboratory Medicine. 2013;21(2):161-169.

20. Verma PK, Raina R, Sultana M, Singh M, Kumar P. Total antioxidant and oxidant status of plasma and renal tissue of cisplatin-induced nephrotoxic rats: protection by floral extracts of Calendula officinalis Linn. Renal failure. 2016;38(1):142-150.

21. Fernandes RDPP, Trindade MA, Tonin FG, Lima CGD, Pugine SMP, Munekata PES, et al. Evaluation of antioxidant capacity of 13 plant extracts by three different methods: cluster analyses applied for selection of the natural extracts with higher antioxidant capacity to replace synthetic antioxidant in lamb burgers. Journal of food science and technology. 2016;53(1):451-460.

22. Shojaee-Aliabadi S, Hosseini H, Mohammadifar MA, Mohammadi A, Ghasemlou M, Ojagh SM, et al.
Characterization of antioxidant-antimicrobial $\kappa$-carrageenan films containing Satureja hortensis essential oil. International journal of biological macromolecules. 2013;52:116124.

23. Kamkar A, Tooriyan F, Jafari M, Bagherzade M, Saadatjou S, Molaee Aghaee E. Antioxidant Activity of Methanol and Ethanol Extracts of Satureja hortensis L. in Soybean Oil. Journal of food quality and hazards control. 2014;1(4):113-119.

24. Najafian S, Zahedifar M. Antioxidant activity and essential oil composition of Satureja hortensis L. as influenced by sulfur fertilizer. Journal of the Science of Food and Agriculture. 2015;95(12):2404-2408.

25. Moghadam L, Reza A. Antioxidant activity and essential oil evaluation of Satureja hortensis L.(Lamiaceae) from Iran. Journal of Essential Oil Bearing Plants. 2015;18(2):455459.

26. Bozari S. Measuring of the Genotoxic and Potential Antioxidant Effects of Essential Oil Obtained from $S$. hortensis Against to Phaseolus vulgaris. Brazilian Archives of Biology and Technology. 2016; 59. http://dx.doi.org/10.1590/1678-43242016160415

27. Yaldiz G, Camlica M. Antioxidant Activities of Satureja hortensis L. Essential Oil during the Flowering Period. Indian Journal of Pharmaceutical Education and Research. 2017;51(3):S258-S261.

28. Şahin F, Karaman I, Güllüce $M$, Öğütçü $H$, Şengül M, Adıgüzel A, et al. Evaluation of antimicrobial activities of $S$. hortensis L. Journal of Ethnopharmacology 2003; 87(1):61-65.

29. Kuete V. Potential of Cameroonian plants and derived products against microbial infections: a review. Planta Med. 2010;76:1479-1491.

30. Awouafack MD, McGaw LJ, Gottfried S, Mbouangouere R, Tane P, Spiteller M, and Eloff JN. Antimicrobial activity and cytotoxicity of the ethanol extract, fractions and eight compounds isolated from Eriosema robustum (Fabaceae). BMC Complementary and Alternative Medicine, 2013;13,289. https://doi.org/10.1186/1472-6882-13-289 